\title{
3 Land Degradation, Ecosystem Services and Resilience of Smallholder Farmers in Makanya Catchment, Tanzania
}

\author{
Line J. Gordon ${ }^{1 *}$ and Elin I. Enfors ${ }^{2 * *}$ \\ ${ }^{1}$ Stockholm Resilience Center, Stockholm University, and Stockholm Environment \\ Institute, SE-106 91 Stockholm, Sweden; ${ }^{2}$ Department of Systems Ecology, \\ Stockholm University, SE-106 91 Stockholm, Sweden; \\ e-mails:*line@ctm.su.se; **elin@ecology.su.se
}

\section{Introduction}

The 'masika' rains, which normally fall between March and May, failed in 2005, causing dramatic yield losses for the smallholder farmers in the Makanya catchment of north-eastern Tanzania. Researchers in the area reported average yields for the season of around $200 \mathrm{~kg} / \mathrm{ha}$. The estimated rainfall during the following short rainy season ('vuli'), which started in October, was $93 \mathrm{~mm}$. Since a minimum of $200 \mathrm{~mm}$ is required to get a crop, this resulted in a complete crop failure. Makanya's people farm mainly for subsistence, and an average of about $80 \%$ of all food eaten is produced within the households ( $\mathrm{K}$. Mshana, Makanya, 2006, personal communication). The masika rains have always been the most important for food production in Makanya. Until the late 1960s, it was the only season in which they cultivated, since the vuli had always been more unreliable. Today, they cultivate in both seasons, and most of them argue that rainfall variability during the masika season has increased and that the importance of the vuli season has, hence, grown.

In this chapter, we look at how Makanya's people coped with the two consecutive lowrainfall seasons in 2005 and 2006, in terms of food security and food self-sufficiency. We focus primarily on the role of local ecosystems in providing important livelihood services during this type of drought. We use the 'agroecosystem' as the unit of analysis, in which we include the interactions between landscape components that are heavily modified by human activities through the exploitation of provisioning ecosystem services (such as food, fuelwood and wild fruit), and the people that shape these ecological processes. The degradation of ecosystem services tends to reduce the resilience of linked social-ecological systems. Previously, we developed a framework for analysing resilience change on dryland smallholder agroecosystems, and applied it to the Makanya catchment (Enfors and Gordon, 2007). In this chapter, we draw on the results presented in the latter paper, which illustrate how the ability (or resilience) to deal with the type of rainfall deficits that Makanya's inhabitants experienced between 2005 and 2006 have declined. We also expand the approach we adopted in the latter paper by analysing resilience in case studies of humandominated social-ecological systems, while making an effort to disentangle some key concepts in resilience analysis.

We define resilience as the capacity of a social-ecological system to cope with disturbances, such as drought, and maintain its 
essential functions when reorganizing after a disturbance (Carpenter et al., 2001). Resilience analysis has primarily been used in a range of ecosystems that are not dominated by human activities, such as lakes, coral reefs and boreal forests (Folke et al., 2004). Recently, there has been an increase in the number of studies of ecosystems dominated by human activities, such as urban areas (Elmqvist et al., 2004) and agroecosystems (Fernandez et al., 2002; Reynolds et al., 2007). Likewise, despite the large literature on the social dimensions of environmental management, efforts to understand resilience of truly linked social-ecological systems have only really taken off over the last 5 to 10 years (Folke, 2006). There remains substantial confusion over how to frame the analysis of these socially and ecologically interlinked systems.

Besides being economically very important for food production, agricultural systems, like all other ecosystems, provide additional services, including carbon sequestration, erosion control, habitat for pests or pollinators, and water modification. Agricultural land use is arguably the dominant driver behind the loss of ecosystem services globally, through trade-offs between increasing provisioning ecosystem services and decreasing the supply of regulating, cultural and supporting ecosystem services (Foley et al., 2005; MEA, 2005). There are plenty of examples from around the world to show that the reduction in regulating and supporting ecosystem services can reduce our ability to continue to increase or even maintain current rates of agricultural production (Molden, 2007). For example, pollination, which is important for $35 \%$ of global crop production (Klein et al., 2007), is threatened in many places by land-use change (Kremen et al., 2007). There are even examples from China where some crops have to be pollinated by hand because of the decline in pollinators (Steffen et al., 2004). Erosion as a consequence of overgrazing is a problem in many grasslands and savannas. Where trees are replaced by annual crops and grasses, water tables can rise. In Australia, this has resulted in salinization over vast dryland areas and substantial yield losses (Gordon et al., 2005). Finally, pest control can be reduced by agricultural intensification. Pesticide use has reduced natural variations in insect populations and predators, while at the same time negatively affecting the broader environment (Cumming and Spiesman, 2006). It is only recently that Integrated Pest Management has emerged, which seeks to maintain insect diversity and associated pest-control benefits. The idea of managing agricultural land to draw on synergies amongst multiple ecosystem services is becoming increasingly common (Foley et al., 2005; Bennett and Balvanera, 2007; Jordan et al., 2007; Kareiva et al., 2007).

Most scientists argue that it is the poor who are most directly dependent on ecosystem services for their livelihoods, and who are also most vulnerable to trade-offs amongst provisioning, regulating and cultural ecosystem services (WRI, 2005). The drylands of subSaharan Africa (SSA) represent some of the most challenging ecosystems in the world to manage in terms of these interacting aspects of hunger, poverty and sustainability (Rockström, 2003; SEI, 2005). 45-50\% of the 250 million people that live here suffer from extreme, and often also persistent, poverty (World Bank, 2005). The majority of the rural poor base their livelihoods on small-scale rainfed agriculture, and current yields may be as low as $1 \mathrm{t} / \mathrm{ha}$. Small-scale agriculture will continue to play an important role in providing livelihood security for people in SSA in the foreseeable future (IFPRI, 2005). With extreme rainfall variability, which gives rise to frequent dry spells and droughts (Barron et al., 2003), and low natural soil fertility (Mortimore, 2005), dryland agroecosystems are both inherently dynamic and vulnerable to land degradation. Figure 3.1 illustrates southern African hot-spot regions, where more than two problems of ecosystem service loss coincide.

To reduce poverty and malnutrition, it is therefore necessary to improve the productivity of current farming systems, while simultaneously safeguarding the generation of other ecosystem services, on which local people also depend (SEI, 2005). Despite recent acknowledgement of changes in the economic structures of these areas, including the increasing role of remittances and income sent home from labour work elsewhere, the heavy dependence on small-scale and lowyield farming means that livelihood security is intimately linked with the productivity of local ecosystems (Speranza et al., 2008). Income 


\section{Distribution of drylands in Africa}

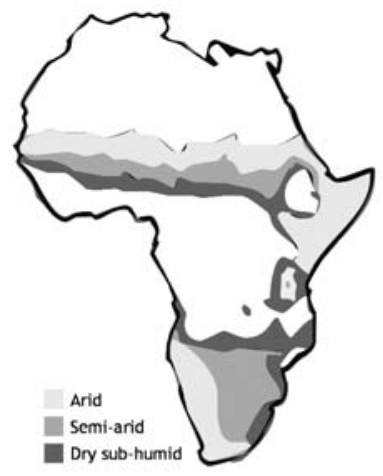

Distribution of drylands map from Land degradation assessment in drylands - LADA project. World Soil Resources Reports No.

97.

Land degradation map adapted from The Southern African Millennium Ecosystem Assessment (SAfMA): Synthesis map illustrating the main areas of concern regarding ecosystem

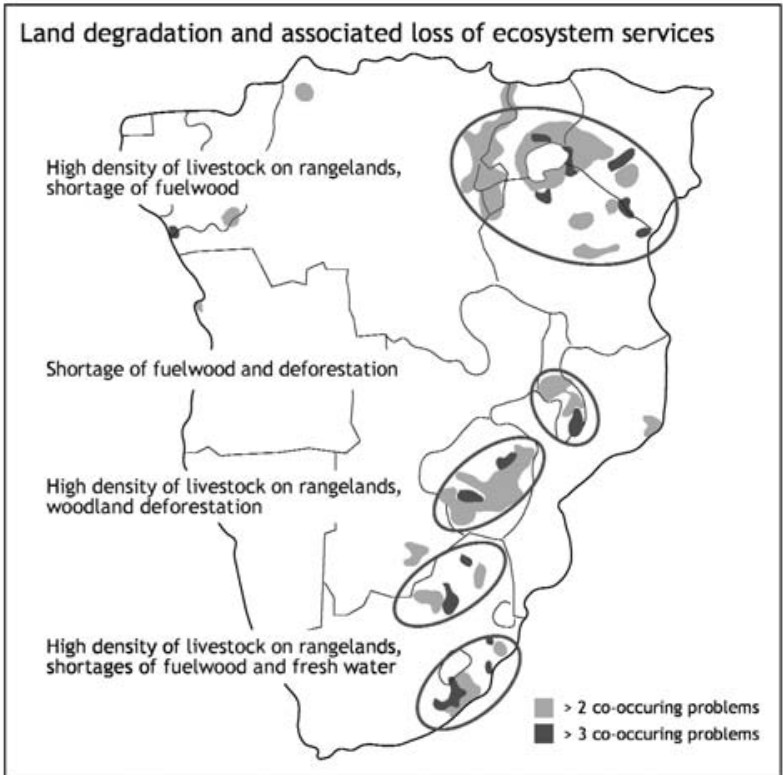

Fig. 3.1. Land degradation and associated loss of ecosystem services in southern Africa. The left map shows the distribution of African drylands, and the right shows the main areas of concern regarding declines in human well-being arising from the loss of ecosystems as a result of land degradation in the drylands of southern Africa, as identified by SAfMA (Biggs et al., 2004). Problems relate mainly to high densities of livestock, deforestation and lack of fresh water.

diversification has long been common in these regions (Ellis, 1998; Barrett et al., 2001). Smallscale, low-input rainfed farming is the primary food and income source for the majority of the SSA population (e.g. $90 \%$ in Malawi, $76 \%$ in Botswana and $85 \%$ in Kenya) (Rockström, 2000) and farmers depend directly on other ecosystem services generated within their local ecosystems, such as livestock and dairy production, fuelwood and construction materials (MEA, 2005).

\section{Resilience and the multiple 'stable states' of agroecosystems}

Ecosystem service trade-offs can thus lead to declines in human well-being and increased vulnerability for people dependent on these services. Generally speaking, ecosystems can tolerate a great deal of abuse before they reach a 'tipping point', and are therefore considered 'stable'. Within a certain stability 'domain', the system can rebound from degradation because its internal regulatory systems enable this quality. If, however, it reaches the tipping point, these internal regulatory mechanisms collapse, and the system's basic characteristics differ considerably from its previous condition and may have little human utility. The latter outcome is particularly true where land degradation causes the system to tip. Such degraded systems are themselves stable, and hence the system can have multiple states, so to speak. Once a system has tipped, restoring it to its previous condition is both difficult and costly, and generally requires heavy application of external resources, such as nutrients and energy subsidies. When an ecosystem reaches a tipping point, and switches from one state to another, it is understood to have undergone a regime shift. Such shifts often come as a surprise. It is in systems where the potential for regime shifts exists that multiple 'stability domains' are said to exist. In a study from Peru, Antle et al. (2006) demonstrate how certain soil conservation technologies may induce agricultural systems to exhibit two equilibria, charac- 
terized by low and high levels of soil degradation. They are separated by a threshold level of soil degradation, beyond which a conservation investment will not yield a positive return. At this point, it is not economically viable to attempt to return the soil to its previous state, even though it may be technically reversible. Thus, this particular threshold or tipping point is not defined by the state of the ecosystem but by economic (societal) conditions. This also implies that once farmers have degraded soils to the point that the system is operating in the lowproductivity domain, a subsidy to encourage the adoption of soil conservation practices will have to be maintained long enough for soil productivity to be restored to the point that the system returns to a high-productivity domain.

Here, we define 'resilience' as the capacity of a system to absorb disturbance and reorganize afterwards, so that the system stays within a particular stability domain (after Carpenter et al., 2001). How these kinds of abrupt changes occur in interlinked social-ecological systems that exhibit multiple stable states and where the structuring variables are not only biophysical is not well researched. The framework that we developed for analysing resilience change in the Makanya catchment (Enfors and Gordon, 2007) was inspired by Fernandez et al.'s (2002) approach in terms of identifying system states, internal feedback and key variables. Below we expand discussion from Enfors and Gordon (2007) on the development of this framework. We also add a discussion about the farmers' dependence on local ecosystem services for understanding the 'identity' and key variables of the system.

\section{Estimating the Resilience of Smallholder Farmers on the Makanya Agroecosystem}

There are a number of ways of estimating resilience in the field and Carpenter et al. (2005) have identified four general approaches: (i) stakeholder assessments through workshops; (ii) model explorations (such as scenarios or computer simulation models) to explore potential thresholds for change, and identify measurable aspects of relationships in the system; (iii) historical profiling, identifying distinct dynamic regimes, and to analyse processes during transitions; and (iv) case study comparisons of systems that change in different ways. In our Makanya case study, we used a mix of stakeholder assessments (through focus groups and interviews), historical profiling and the development of a conceptual model. A necessary first part of the analysis is to pose the question: 'resilience of what (which system/what aspects) to what (which disturbances/surprises)?' (Carpenter et al. 2001). To answer this question, two steps are required: (i) that the studied system's identity is defined in terms of scale of analysis, actors involved, their use of ecosystem services and the disturbance regimes to which the system are expected to be resilient; and (ii) that potential system states and key structuring variables are identified.

\section{Identity of the system}

Agroecosystems can be difficult to define because they are strongly influenced by both biophysical and social factors. We chose to focus the analysis on the smallholder farmers (the actors) in the Makanya catchment in Tanzania (the spatial scale of analysis) (see Box 3.1). In initial interviews (for methodology see Box 3.2) with farmers and other stakeholders in the region, we discussed the various disturbances with which the system had to cope. Based on this, we focused on how the capacity of this system to cope with droughts and dry spells changed over time.

In terms of dependence on ecosystem services, many areas in sub-Saharan Africa (SSA) experience different levels of agricultural decline, with a larger proportion of incomes and livelihood support coming from, for example, seasonal migration and remittances from urban areas (Barrett et al., 2001). To understand the extent to which local ecosystem services, including food production, play a role in the local economy we conducted two series of interviews with 60 households in the area (see Box 3.2), focusing on local food security and income generation during the drought years of 2005-2006. The results are presented below. 
Box 3.1. The case study area.

The Makanya catchment is wedged between two mountain ridges in the South Pare Mountains of Tanzania's Kilimanjaro Region (Fig. 3.2). The catchment's estimated population is 40,000 people (United Republic of Tanzania, 2002). The river rises at about $1500 \mathrm{~m}$ above sea level. Climate, ecology and demographics change as it descends. The rain pattern is bimodal, with a long rainy season, the 'masika', between March and June, and a shorter rainy season, 'vuli', between October and December. The population depends mainly on resources generated locally (i.e. within the catchment). Three villages were selected to represent a cross-section of the catchment: Vudee-Ndolwa upstream, Bangalala midstream and Makanya downstream (Fig. 3.2).

In the highlands, annual precipitation averages $800-900 \mathrm{~mm}$, and falls mainly during storms, which produce large amounts of runoff that is diverted into tanks and canals for irrigation further downstream. People in the highlands derive livelihoods from small-scale farming, including some agroforestry. The main crops are maize, vegetables, fruit and coffee. The population density is high and there is a land shortage. Midstream in the catchment, rainfall averages 500-600 mm/year, although with high variation, and it is hotter and drier than upstream. The landscape is dominated by cropland, but relatively large areas of bushland (used for grazing) also cover this part of the catchment. People live off small-scale farming in combination with herding. They mainly produce maize and beans, but also vegetables adjacent to indigenous irrigation dams ('ndiva') and canals. Population density is lower than in the highlands. Downstream in the catchment, scattered low-growing bushes and solitary trees characterize the dry savannah (miombo) landscape. Rainfall is low, often below $500 \mathrm{~mm}$ annually, and farming is dependent on floods, which occur a few times yearly. The only crops grown by the smallholders are maize and beans. Crop failure due to water deficit is common, and herding is considerably more important here than upstream as a source of livelihood. The population density here is low, and land is abundant. In addition to farming and pastoralism, people in the catchment earn incomes from small-scale business based on local resources and produce. Cash crops and other products are mainly sold at local markets.
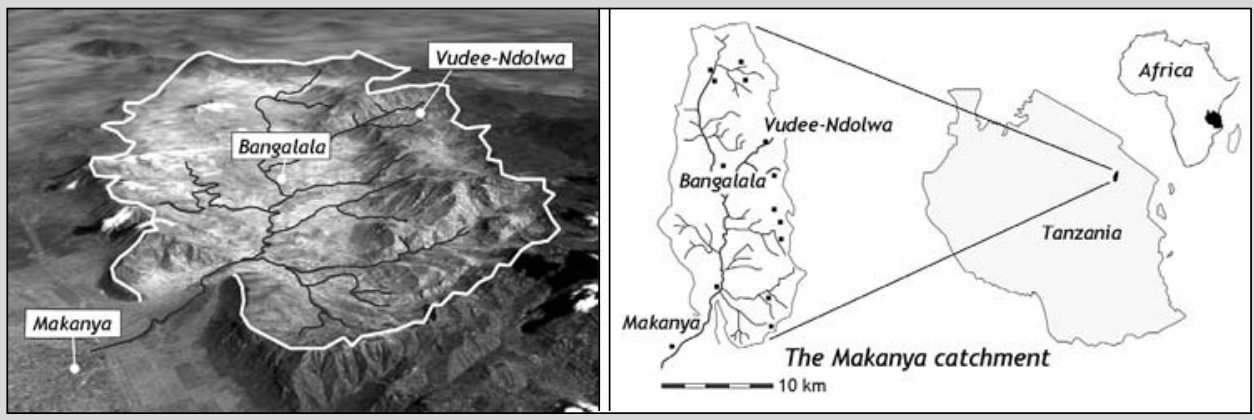

Fig. 3.2. The Makanya catchment. Left, the study villages; right, the location of the catchment in north-eastern Tanzania. Satellite image background from Google Earth/Earthsat 2005.

\section{Food security in 2005-2006}

Food security became an issue in the catchment following reduced harvests after the vuli season (end of January 2006). More than two-thirds of the interviewed households stated that they experienced food shortages, which meant that they had to adopt coping strategies, such as changing their diets, reducing the amount of food per meal and/or reducing the number of meals eaten per day. There was no prospect of producing a new crop until June or July that year. There were only eight households out of 60 interviewed that had harvests from the vuli season, and mainly because they had access to fields outside the catchment.

Figure 3.3 shows the relative importance of different food sources. On average, only $20 \%$ of household food requirements were met by their own farming systems (including this season's harvests, storage from previous harvests, poultry and livestock. In a 'normal' 
Box 3.2. Interviews in Makanya - methods used.

Data for studying drought-coping strategies were collected in two series of semi-structured interviews (c.f. Bernard, 1994) following the masika and vuli rains, respectively. Farmers from 60 different households were interviewed. All households were interviewed on both occasions, except for six that were unavailable during the second interview series. The interviewees came from two villages located in the midstream of the catchment (see Box 3.1), and were either head of their households or among the household breadwinners. They were chosen in agreement with a village spokesperson, so that they would represent households of different size, income status and sub-locations. Out of the 60 respondents, 35 were men and 25 were women, and their age range was 25-75 years.

One of the interview series included a ranking exercise (see e.g. Mikkelsen, 1995), where respondents were asked to rank their current food and income sources in order of importance. The ranking aimed to answer two main questions: (i) from where do you get your food during this season?; and (ii) from where do you get the income for this food? In addition to the qualitative information obtained from the interviews, this provided a quantitative approximation of the importance of different food and income sources used after the drought. During the interviews other subjects were also discussed: (i) perceptions of food security and strategies to deal with drought, including preparation for food shortages; (ii) management of the farming system, including the use of fertilizers and labour investment in different fields (irrigated/non-irrigated); and (iii) the use of the larger agroecosystem in general and crop-complementing resources (such as livestock and forest products) in particular, focusing on this as a strategy for dealing with yield reductions.

To gain an understanding of the local people's views on the agroecological changes in the area during the past 50 years, and of the perceived driving forces behind these changes, semi-structured interviews were held with elderly farmers (over 60 years old) in the three study villages. The interviews covered issues such as rainfall dynamics, soil quality, farming practices, strategies for landscape management, use and availability of provisioning ecosystem services and local demographics, all of which are factors affecting the local soil water index and ecosystem insurance capacity. In total, 70 farmers were interviewed, men and women equally. These discussions were held with smallholders from three different villages across the catchment. Interviewees often paint a past far better than it actually was. We therefore used a range of different ways to supplement the interview data, including the development of timelines describing the area's social, political and ecological history in focus group discussions (see e.g. Mikkelsen, 1995), complementary interviews with extension workers in the catchment and with local authorities in Same District, and the use of quantitative biophysical data including analysis of land cover change, rainfall variability and population data (see Enfors and Gordon, 2007). Furthermore, although we were interested in actual biophysical changes as perceived by the farmers, we also asked about how management and associated institutions had changed over time. This can be seen as another way to check the data on perceived changes in the resource base, since institutional change is a key driver for resource change, and this needs to be a consistent story. This analysis included literature data as well.

season, $80 \%$ of food would have been derived from the vuli harvest ( $\mathrm{K}$. Mshana, Makanya, 2006, personal communication). Harvesting fruit and wild vegetables contributed another $11 \%$.

\section{Income sources for food purchases}

The range of strategies that households deployed in order to secure incomes with which to cover the increased costs of buying food are summarized in Table 3.1. People used savings, tried to increase their incomes and obtained remittances. They also used capital and re- sources accumulated over the preceding seasons. For example, one informant had spent months making bricks to build a new house for his family, but he was forced to sell them at a price well below normal to be able to buy maize. Thus, the family food needs were met, at least provisionally, but at the expense of improved housing. Other informants complained that, since they had to use their savings for food, it was impossible to maintain normal small-scale businesses like buying food in town, where the prices are lower, and selling it in the villages, where they are higher. Comments similar to the ones below were made by at least one-third of informants: 


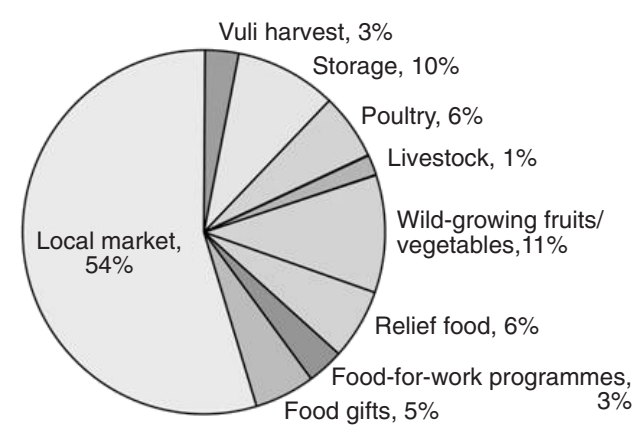

Fig. 3.3. Relative importance of various food sources after the May-June 2005 drought.

'I had saved money for other purposes, but now I had to use it for food instead.'

'I spend much more on food now, and had to stop building a house that we had started.'

' $95 \%$ of our income goes to food now, and therefore we can't afford tuition for our children.' ' $90 \%$ of the income was used for food this season. Normally I sell fish, but I have nothing to invest in the business now.'

An additional problem was that cash crops such as tomatoes, onions, cabbages and beans, which normally serve as the main income source in the area, were also affected by the lack of rain, making people increasingly reliant on income sources that were less rainfall-dependent, such as livestock and forest products, although livestock prices dropped dramatically during this time.

A substantial contribution to household nutrition therefore came from the local environment's capacity to generate goods that could provide an alternative income when harvests failed. In the study area, $85 \%$ of the interviewed households earned incomes based on locally generated provisioning ecosystem services such as fibre, wood products, wild fruit, and fodder for free-ranging livestock. On average, more than $40 \%$ of the total incomes came from these sources, making it the most important income sector in the area. This illustrates the dependence of smallholders on the local ecosystem, despite a growing consensus that income diversification towards non-agroecosystem sources is an increasingly important strategy to cope with drought (Barrett et al., 2001).

\section{System states and key structuring variables}

Given the importance of provisioning ecosystem services for Makanya's inhabitants, we suggest that a resilient system in the context of

Table 3.1. Sources of household food expenditure after the drought.

\begin{tabular}{lccc}
\hline Source & $\begin{array}{c}\text { Users who use the } \\
\text { Households using } \\
\text { the source (\%) }\end{array}$ & $\begin{array}{c}\text { Total amount of } \\
\text { source for income } \\
\text { contribution (\%) }\end{array}$ & $\begin{array}{c}\text { income } \\
\text { contribution (\%) }\end{array}$ \\
\hline $\begin{array}{l}\text { Income based on local ecosystem } \\
\quad \text { provisioning services }\end{array}$ & 85 & 48 & 42 \\
Cash crops (own or locally produced) & 32 & 39 & 12 \\
Livestock & 50 & 31 & 16 \\
Charcoal & 6 & 9 & 1 \\
Bricks & 11 & 26 & 3 \\
Timber & 4 & 15 & 1 \\
Handicrafts & 15 & 24 & 4 \\
Other agroecosystem-based business ${ }^{b}$ & 21 & 24 & 5 \\
Wage labourc & 55 & 41 & 22 \\
Savings & 43 & 33 & 14 \\
Remittances & 38 & 32 & 12 \\
Business & 23 & 41 & 6 \\
Off-farm employment & 8 & 58 & 4
\end{tabular}

a The importance of charcoal is probably underestimated, since charcoal making is illegal and informants therefore are reluctant to admit to engaging in it. In contrast to these figures, the qualitative data suggest that it is one of the main income sources in the area when harvests fail.

${ }^{b}$ E.g. selling wild fruit or firewood.

c Mostly labour on neighbouring farms or construction work. 
the Makanya catchment is a system that over time maintains its capacity to generate food and other vital ecosystem services for the catchment's population, and that it is sufficient to cope during times of drought.

In Enfors and Gordon (2007), we identified two alternative stability domains for smallholder agroecosystems in dryland environments (adapted from Fernandez et al., 2002). Under the first (the 'productive' domain), the generation of adequate biophysical resources to support the catchment's people is assured over time. This means that the feedbacks between people and the catchment's ecosystems maintains, or even improves, productive potential. In the other domain (the 'degraded' domain), management practices trigger a set of feedbacks that degrade the resource base over time. 'Degraded' is thus defined as a system that cannot meet the current and expected future needs of the area's population. Capacity remains low, or becomes increasingly degraded over time.

\section{Identifying key variables}

The dynamics and behaviour of highly complex socio-ecological systems are structured by the interaction of a large number of variables. Often, however, there are only three to five key variables (Gunderson and Holling, 2002). In Enfors and Gordon (2007), we chose to search for two combined socio-ecological variables that related to processes that either sustained or reduced the productivity of the resource base, and which were characterized by some critical level (threshold) where a change took place in feedbacks of the combined social-ecological system.

The first of these was the soil water index (SWI), which includes aspects of local food production capacity and water availability at the field scale. The way that SWI determines feedback into the system is illustrated in Fig. 3.4a. With a higher SWI, there is a lower risk of crop failure, and higher total biomass, providing farmers with incentives to invest in the farm (Enfors, 2007, unpublished thesis). More biomass can also be left on the field and organic matter can be built up. Better investments can lead to higher nutrient availability. High nutrient availability and organic matter combined increases SWI. If SWI gets too low, however, there is an increased risk of crop failure and lower biomass production. This reduces incentives for farmers to invest in the field and sustains a feedback loop that drains the system of resources. The change in feedback between the productive and degrading loops represents a threshold.

The second variable is ecosystem insurance capacity (EIC), and was chosen to include those aspects of landscape-level provisioning ecosystem services that were shown to be vital for coping capacities during drought in the Makanya catchment. Although the level of resource inputs from outside sources (e.g. remittances and seasonal migration from elsewhere) have probably increased in Makanya over the last few decades, these still represent a relatively small source of livelihood security in times of crop failure (Table 3.1). EIC is only relevant as a variable in systems where people are very dependent on the local resource base for ecosystem services, and the increasing livelihood diversification elsewhere in SSA will probably reduce the importance of this variable and increase the importance of others. We suggest that the feedbacks that influence EIC in regions of land scarcity (and not where land is abundant) are intimately connected to management practices and the institutions that regulate these (Fig. 3.4b). Here, we draw on North (1990) to define institutions as the norms and rules that regulate human behaviour and shape human interactions, in this case with the environment. Some societies have management practices that nurture the resource base in order to provide particular support during disturbances (Colding et al., 2003; Tengö and Hammer, 2003). For example, rangeland pastoralists in the Sahel use buffer zones that are protected from grazing except in emergency situations such as during prolonged droughts (NiamirFuller, 1998). Management strategies like this thus increase EIC. Although an increasing population leads to a higher demand for provisioning ecosystem services, population growth does not necessarily result in a decreased EIC. Depending on the institutions developing in response to higher demands, population growth can generate improved management regimes (cf. Tiffen et al., 1994).

The two variables interact by increasing or reducing resilience to regime shifts. If, for example, the SWI threshold is crossed, average 
(a)

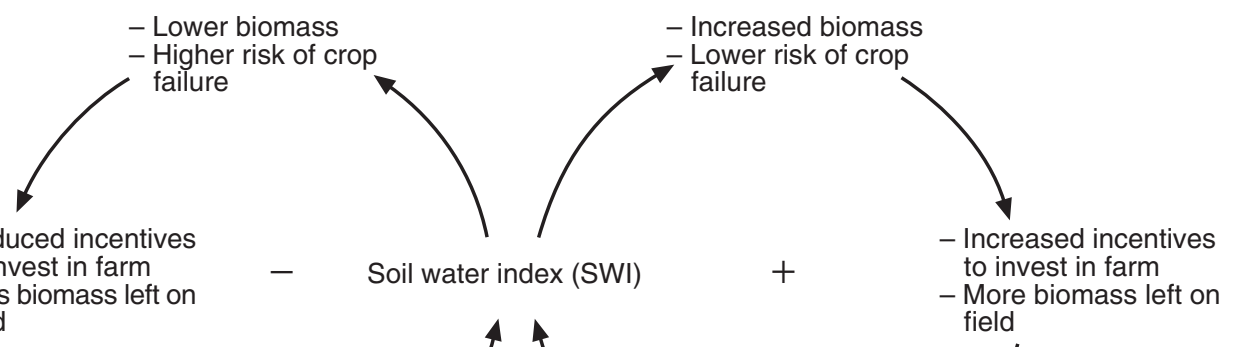

(b)
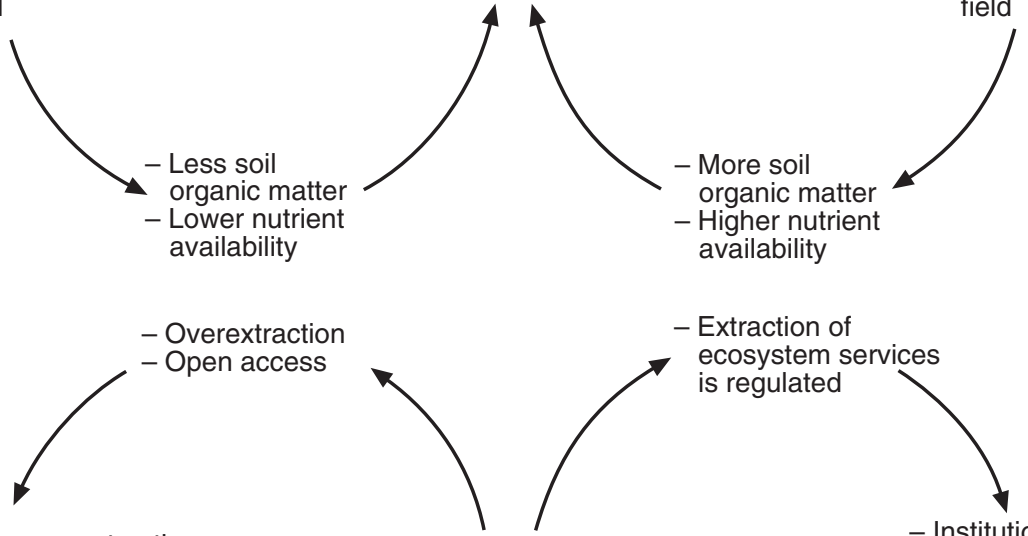

- Extraction of ecosystem services is regulated
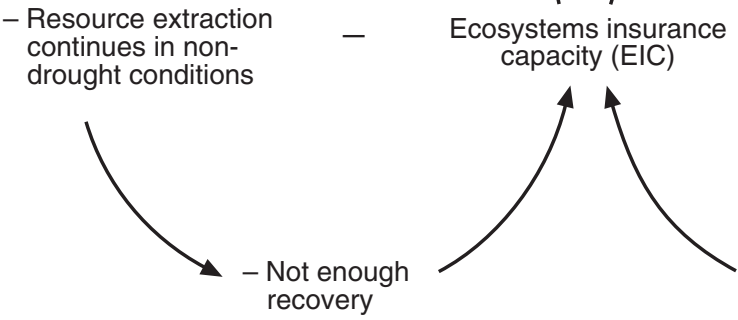
capacity (EIC)
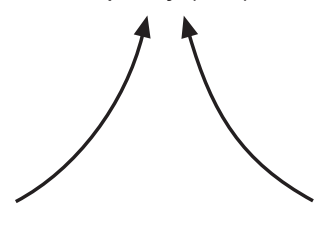

- Recovery

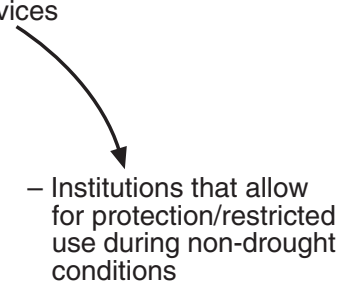

Fig. 3.4. Feedback loops that sustain either a productive state or a degrading state in relation to (a) soil water index (SWI) and (b) ecosystem insurance capacity (EIC).

harvests decline and people become more dependent on the insurance capacity of the surrounding ecosystem and increase exploitation of this, increasing the risk that the EIC threshold will also be crossed. The further away from the threshold in either direction, the greater the resilience of the system. In a 'productive' state, this is obviously positive because it reflects an improved capacity to generate agricultural products and other ecosystem services. Increasing resilience in a degraded state, however, represents the increasing efforts and costs that will be needed to push the system into the more desirable state (Fernandez et al., 2002). To a certain extent, it is also possible to 'move' the thresholds, affecting the relative position of the system, and increasing or decreasing the space of the produc- tive and degraded domains, respectively (Fernandez et al., 2002). The EIC threshold can be lowered by increasing people's access to remittances through the social networks they belong to, reducing the need to exploit the resource base. The SWI threshold can be lowered by shifting to more drought-tolerant crops.

The data we gathered to assemble these variables are summarized in Table 3.2. These represent 'proxies', given that determining SWI and EIC requires long data time-series. In the absence of these, we looked for proxies for which it is possible to get data.

A number of factors affect the system's position along the SWI axis (Fig. 3.5), and thus its distance to the threshold. The system will move to the left if water availability declines, as would 
Table 3.2. Proxies for estimating changes in key variables. The methods for the analysis of these proxies are described in more detail elsewhere (Enfors and Gordon, 2007; see also Box 3.2).

\begin{tabular}{|c|c|c|}
\hline Key variable & Proxy & Type of analysis \\
\hline \multirow[t]{4}{*}{ Soil water index } & Rainfall analysis & Data \\
\hline & Population growth & Data \\
\hline & Changes in fallow systems and management practices & Interviews \\
\hline & Perceived changes in rainfall & Interviews \\
\hline \multirow[t]{4}{*}{$\begin{array}{l}\text { Ecosystem insurance } \\
\text { capacity }\end{array}$} & $\begin{array}{l}\text { Land cover change analysis of aerial photos and satellite } \\
\text { images }\end{array}$ & Data \\
\hline & Perceived changes in the resource base & Interviews \\
\hline & $\begin{array}{l}\text { Changes in institutions for resource management locally } \\
\text { and nationally }\end{array}$ & Interviews \\
\hline & Political changes in the region & Literature \\
\hline
\end{tabular}

occur during drought. This can be captured in an analysis of rainfall dynamics over time. Since biomass is removed from the soil when harvesting, soils become impoverished over time if active measures are not taken to sustain nutrient and organic matter levels (Koning and Smaling, 2005). This affects water availability in the root zone and plant productivity responds negatively, thus lowering the SWI and moving the system to the left. Management of the farming system, including cropping intensity and fallowing, crop choice, nutrient handling, tillage methods, etc., can also affect this, either by speeding up the process or by counteracting it, and could thus move the system in either direction along the axis. We seek to capture this in our analysis by looking at: (i) changes in fallow systems; and (ii) changes in management practices. Finally, population growth can also affect the system's position, since it can result in less arable land available per capita. We thus look at population data. We also used interviews with farmers to capture the changes in soil water index as perceived by the farmers.

For EIC, we analysed the availability of resources by looking at the area coverage of different land uses, and by interviews with the farmers related to perceived changes in the resource base to capture the more qualitative aspects of changes in ecosystem services. The direction in which the system moves along the EIC axis depends to a large extent on the management of the resources in question (Fig. 3.5). We therefore analyse institutional changes as they relate to management of resources at the local scale, and how this has interacted with larger-scale political changes in Tanzania.

\section{Changes in Resilience in Makanya Catchment}

To analyse socio-ecological changes in the case study area over time, Tanzania's history during the past century was divided into three periods (Enfors and Gordon, 2007): (i) the colonial period, which started in the late 19th century and ended in the early 1960s; (ii) the independence period and African socialism, 1961-1985; and (c) the period of economic liberalization, 1985-present.

\section{Soil water index}

\section{Perceived changes in rainfall and soil quality}

There was general consensus amongst farmers that rainfall was higher during the first period of analysis (the colonial period) than today. Farmers often mentioned that they only needed to cultivate the land during the masika season and they felt that the soils were more fertile during this period. Fallowing was practised. They stated that rainfall started to decline during the second period of analysis. Farmers responded to the decline by opening up new fields, especially in the mid- and lowlands and also began cultivating during the vuli season. This transition from single to double annual cropping cycles marked an intensification of the farming system. According to the farmers, land scarcity increased in the upper and middle parts of the catchment. The farmers also stated that the last few years had been especially dry, affecting the whole landscape and, in particular, agricultural yields. Some 


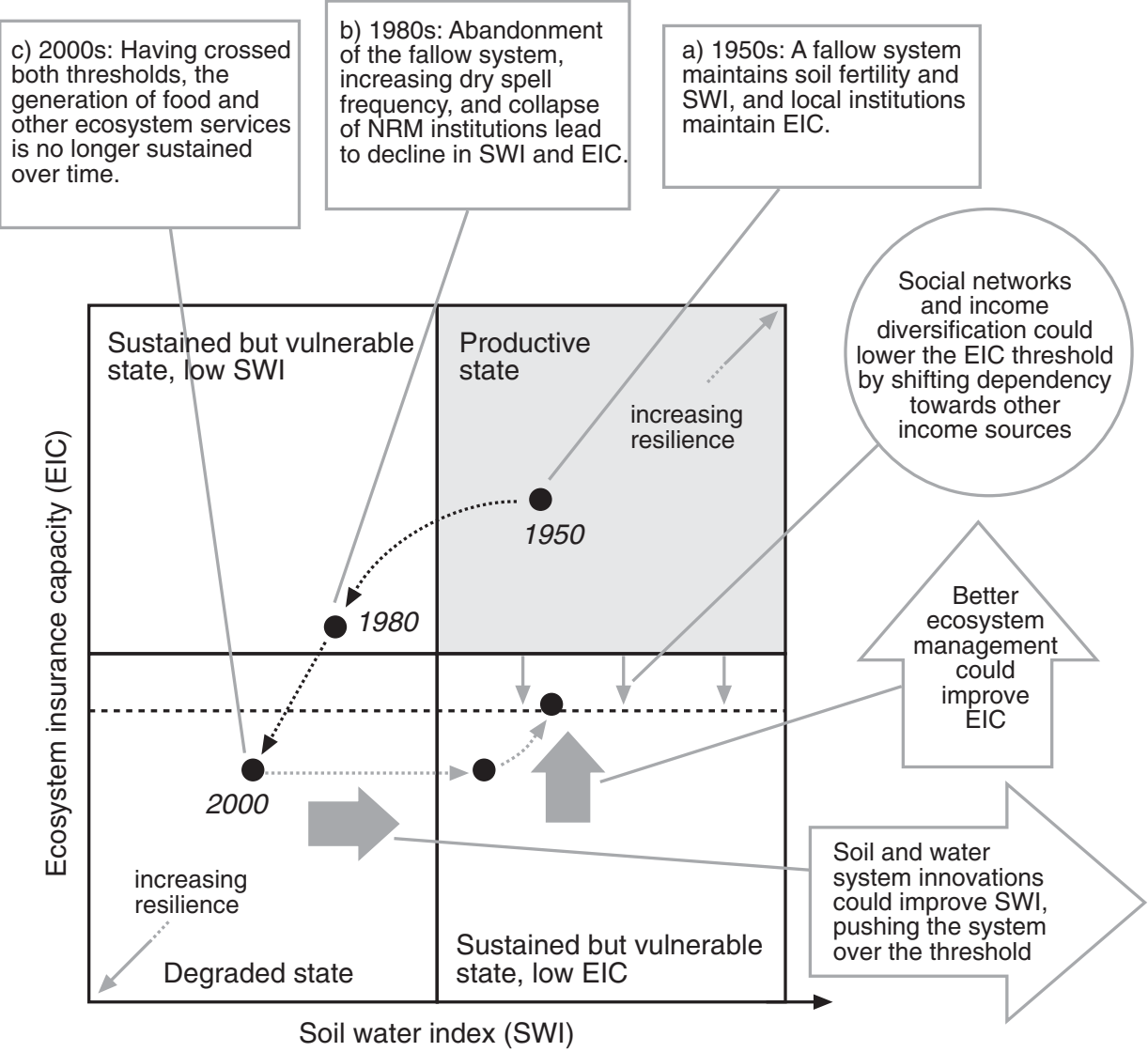

Fig. 3.5. Changing the trajectory of development. (a) We suggest that the Makanya catchment agroecosystem has moved from a productive to a degraded state since the mid-1950s, which, when combined with an increase in dry spells, led to a decline in SWI, and the system crossed the first threshold. We propose that the system crossed EIC threshold around 1980 and moved into a degraded state. Today agricultural products and other ecosystem services are not generated fast enough to support the system's population over time; current resource exploitation trends are eroding productive capacity. (b) There would appear to be an opportunity to reverse degradation trends in the Makanya catchment. The use of small-scale soil and water system innovations such as drip irrigation, conservation tillage and water harvesting could move the system to the right along the SWI axis, and improved local institutions for management of cropcomplementing resources could move it upwards along the EIC axis.

claimed that rainfall dynamics had changed so that vuli has become the better of the two growing seasons. Virtually all farmers now cultivate in both seasons, and the use of extended fallow periods has largely been abandoned. Farmers in the mid- and downstream areas of the catchment mention that erosion has accelerated following upstream logging, and almost all informants said that soil fertility had declined.

\section{Rainfall analysis}

The rainfall analysis (for methods see Enfors and Gordon, 2007) revealed high variability in both annual and seasonal rainfall. Over time, the masika season rainfall seems to have followed a declining trend, whereas rainfall during vuli seasons, although highly variable, seems unchanged. Statistically, however, neither of the 
trend-lines represents any significant changes. A significant increase in the frequency of long dry spells (21 days or longer) was found during the masika. Between 1957 and 1980, a dry spell of 21 days or longer occurred in $42 \%$ of the masika seasons, while the same was true of $79 \%$ of masika seasons between 1981 and 2004 (Fig. 3.6). The long dry spells often occur late in the season, at some time between days 50 and 70 . This is the most drought-sensitive growth stage for maize, and long dry spells during this period are most likely to lead to severe yield reductions. The severe impact of dry spells on yields during this stage probably explains (at least in part) why the local farmers feel that it rains less today, and why some of them say that vuli is becoming the more important cropping season.

\section{Population growth}

Based on annual average growth rates for the district and the region in which Makanya is located, the population in the area is estimated to have increased by approximately $200 \%$ since the late 1950s. Much of this growth took place during the first half of the period, when the population growth in the region was above $3 \%$ annually (United Republic of Tanzania, 2002).

\section{Ecosystem insurance capacity}

Perceived changes in the resource base and the institutions for the management of natural resources (Enfors and Gordons (2007), summarized in Table 3.3)

Informants describe abundant wildlife, and claim that natural resources used in daily life, such as firewood, timber, grasses, wild vegetables and fruit, medicinal plants, honey and fibres, were readily available in the catchment during the colonial period. Furthermore, they argued that the use of these resources was regulated both by strong local institutions and by externally imposed laws. Informants described how an increasing land area was put under agricultural production in the catchment as the population grew and rainfall declined during the independence period, and how people started to disregard existing regulations for natural resource protection. For example, in the densely populated highlands, the lack of arable land led to the cultivation of steep slopes, despite these areas being protected. Respondents further described how vegetation cover throughout the catchment decreased as a consequence of agricultural expansion. Another important change in the ecology of the catchment at this time was the disappearance of larger wild animals.

During the economic liberalization period, there was an increase in land conversions, which caused a reduction in grazing area, and conflict between pastoralists and farmers became increasingly common. Illegal logging is considered by local authorities as one of the more serious problems in the area today. In addition to agricultural expansion, growing needs for firewood and escalating charcoal manufacture were seen as the main drivers behind this. The rise in charcoal manufacture is explained by declining harvests and a lack of alternative income sources for the farmers. It is generally perceived that natural resources used in daily life, especially firewood, but also grass, local medicines and honey, were becoming increasingly difficult to find in the catchment. In summary, informants were of the opinion that the local resource base had gradually become more degraded over the past $40-50$ years.

\section{Land cover change analysis}

The change detection showed that cultivated land had noticeably increased in the catchment since the mid-1950s, covering about $37 \%$ in $1954,44 \%$ in $1982 / 83$ and $55 \%$ in 2001 .

Occurrence of dry spells 21 days or longer during Masika seasons, 1957-2004

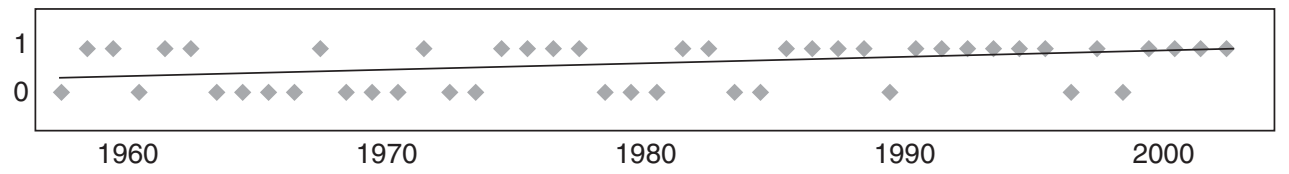

Fig. 3.6. Dry spells in the Makanya catchment. Change in dry spell frequency, 1960 to 2000 . 
Table 3.3. Three periods of change. The table summarizes the three time periods, focusing on sociopolitical structure, strategies for governance of natural resources and local people's perceptions of the agroecological conditions. Based on Enfors and Gordon (2007).

\begin{tabular}{|c|c|c|c|}
\hline & Colonial period, to 1961 & $\begin{array}{l}\text { Development of independent } \\
\text { Tanzania, 1961-1985 }\end{array}$ & $\begin{array}{l}\text { Economic liberalization, } \\
\text { 1985-present }\end{array}$ \\
\hline $\begin{array}{l}\text { Socio-political } \\
\text { structure }\end{array}$ & $\begin{array}{l}\text { Low, subsistence-based } \\
\text { population } \\
\text { The colonials rule through } \\
\text { local chiefs } \\
\text { Imposed cash-crop } \\
\text { production }\end{array}$ & $\begin{array}{l}\text { Population growth } \\
\text { Socialism, self-reliance and } \\
\text { ujamaa become national } \\
\text { goals } \\
\text { 'Villagization' } \\
\text { Economic decline starting } \\
\text { in the 1970s }\end{array}$ & $\begin{array}{l}\text { Economic crisis leads to } \\
\text { reforms and structural } \\
\text { adjustment } \\
\text { Multi-party system } \\
\text { adopted } \\
\text { NGOs become important } \\
\text { actors in rural } \\
\text { development } \\
\text { Participation on the } \\
\text { agenda }\end{array}$ \\
\hline $\begin{array}{c}\text { Natural resource } \\
\text { management }\end{array}$ & $\begin{array}{l}\text { Colonial laws to protect } \\
\text { land, water and forests } \\
\text { exist parallel to local } \\
\text { institutions for resource } \\
\text { access and control } \\
\text { Local chiefs enforce } \\
\text { these rules and laws }\end{array}$ & $\begin{array}{l}\text { Replacement of local chiefs } \\
\text { leads to weaker protection } \\
\text { of natural resources } \\
\text { Farming and livestock } \\
\text { keeping more permanent } \\
\text { following villagization } \\
\text { By-laws created to protect } \\
\text { the environment }\end{array}$ & $\begin{array}{l}\text { By-laws for environ- } \\
\text { mental protection } \\
\text { inefficient } \\
\text { Far-reaching policy } \\
\text { changes make } \\
\text { alternative forms of } \\
\text { natural resource } \\
\text { management possible }\end{array}$ \\
\hline $\begin{array}{l}\text { Perceptions of } \\
\text { agroecological } \\
\text { conditions }\end{array}$ & $\begin{array}{l}\text { Natural resources used in } \\
\text { daily life are readily available } \\
\text { More reliable rainfall and } \\
\text { higher soil fertility } \\
\text { Only a small portion of the } \\
\text { land used for farming } \\
\text { Farmers only cultivate one } \\
\text { season per year }\end{array}$ & $\begin{array}{l}\text { Expansion of agricultural } \\
\text { land, farmers cultivate } \\
\text { both seasons } \\
\text { Protected areas encroached } \\
\text { upon } \\
\text { Decreasing forest/ bushland } \\
\text { cover } \\
\text { Disappearance of wildlife } \\
\text { Decreasing rainfall }\end{array}$ & $\begin{array}{l}\text { Lack of farming land in } \\
\text { spite of expansion, } \\
\text { declining soil fertility } \\
\text { Large-scale illegal } \\
\text { logging } \\
\text { Natural resources used } \\
\text { in daily life difficult to } \\
\text { find } \\
\text { Low rainfall and population } \\
\text { growth seen as reasons } \\
\text { behind changes }\end{array}$ \\
\hline
\end{tabular}

During the same period, the area of sparse bushland decreased from 57 to $41 \%$. These land conversions probably explain the reduced availability of ecosystem services such as livestock fodder, firewood and local medicines.

\section{Interactions between the variables}

Before 1960, it would appear that the Makanya system was productive (Enfors and Gordon, 2007). Farming intensification, the loss of fallow systems and low levels of nutrient input have led to depleted soils. This, along with the increasing dry-spell frequency, has affected the SWI negatively, and the system started moving to the left in Fig. 3.5.
The simultaneous change in several different factors, we argue, caused the system to move into an unproductive domain. Changing rainfall dynamics, population growth and declining soil quality undermined the biophysical variables in the system. There are plenty of success stories of communities who have managed to turn such a negative trend around. In Makanya, however, Tanzania's independence gave rise to profound social and institutional change that served to undermine local institutions, including those relating to resource access and control. When both biophysical and social systems were weakened, resilience was reduced. The system moved downwards along the $y$-axis, approaching the EIC threshold (Fig. 3.5). We suggest that this happened in the late 1970s or early 1980s, 
and hypothesize that this triggered a spiral of mutually reinforcing feedbacks, involving increased cropping intensity, cultivation of more marginal land, yield declines, soil fertility decline and the general loss of provisioning ecosystem services. This would mean that the system develops along a trajectory where food and other ecosystem services are not generated fast enough to support a human community over time, and where current agricultural techniques and natural resource management practices erode productive capacity.

\section{Discussion: from Trap to Transformation?}

This case study illustrates the present challenge of breaking out of feedback loops that sustain a less productive trajectory for development. It reveals the need for the improved management of semi-arid agroecosystems, and reversing the degradation trends seen both here and in other drylands (MEA, 2005). We suggest that in order to shift the system into a more productive state there needs to be simultaneous investment in several different resources, including both biophysical and social ones. To change trajectories such as the one described here is not easy. We have previously argued that there exists a 'window of opportunity' for changing the trajectory in Makanya at present (Enfors and Gordon, 2007). It has been suggested that these windows open with the convergence of three independent conditions: (i) there is general awareness of the problem; (ii) practical solutions are available; and (iii) there is a sense of willingness and capacity for political action (Kingdon, 1995; Olsson et al., 2006). In the Makanya catchment, there are a number of on-going internal and external processes relevant in this context. Makanya's people are aware of the degradation trends in the catchment; various forms of smallscale soil and water system technologies that could potentially help reverse the degradation are available; and local institutional capacity is improving, facilitating political action. Consequently, some of the conditions required to initiate change do seem to exist. People's expectations of the future and their ideas about desirable development, however, obviously also influence the potential for changing the system's trajectory. This, and factors such as leadership and access to resources outside the catchment, will, in the end, determine the capacity to take advantage of this window of opportunity.

Depending on the extent of degradation, rehabilitating the land may well be difficult and costly. To some extent, there is also a need to focus on the development of coping strategies at larger scales, especially in cases when it will be too costly, too difficult or take too long to fully recover the system's resource base. It has been suggested elsewhere that many smallholder farmers in dryland areas of sub-Saharan Africa are stuck in 'poverty traps' (Barrett and Swallow, 2006). Land degradation increases human vulnerability to disturbances such as dry spells, droughts and floods. As was seen in the examples of coping strategies, the farmers in Makanya tend to exhaust their resources when droughts occur, effectively stopping them from either continuing with businesses or improving their situation. Land degradation thus increases the frequency with which smallholders are affected by these disturbances, forcing them to exhaust their accumulated resources more often in a degraded than in a non-degraded system. This suggests that land degradation deepens the poverty trap, decreasing the likelihood of a shift to a higher welfare equilibrium (Fig. 3.7).

Improved agroecological productivity would probably position the system closer to the threshold for such a shift in strategies, although this is by no means guaranteed. It seems likely that if the transition in strategies is to come from within the system, a relatively high agroecological productivity will be required. If, however, the process is driven by externally sourced resources, a shift may be possible in any case, since this could make the system independent from the variables currently structuring its development (the soil water index and ecosystem insurance capacity). Regardless, a transition from the lower welfare equilibrium to a higher one would most likely mean that the key structuring variables in the system would change, and that the system's boundaries would need to be redefined. 


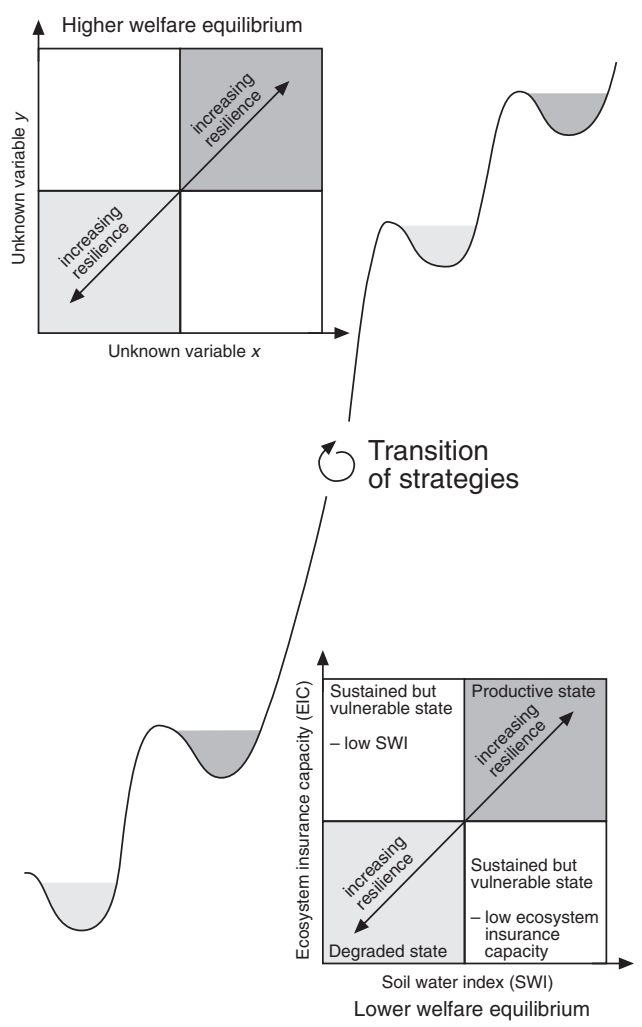

Fig. 3.7. Agroecological productivity and welfare dynamics. SWI and EIC constitute the structuring variables for the system in the lower welfare equilibrium. Land degradation increases vulnerability to disturbances such as dry spells, droughts and floods. Harvests will fail more frequently in a degraded than in a non-degraded system, forcing smallholders to exhaust accumulated resources more frequently, and aggravating a potential poverty trap. This makes a shift to the higher welfare equilibrium increasingly difficult. Conversely, improved agroecological productivity would probably facilitate the transition of strategies.

\section{Conclusions}

In this chapter, we have analysed the capacity of the farmers in the Makanya catchment to cope with droughts and dry spells between 2005 and 2006, and showed that they did have strategies to cope with this. We illustrated that $85 \%$ of households in our sample sites used ecosystem services to generate income with which to buy food in situations of drought, and that, on average, $42 \%$ of the income for food purchases came from ecosystem services. We also showed that another important recent strategy has been to use savings, which often prevented farmers from engaging in businesses and from improving their livelihoods, potentially revealing a poverty trap.
We then developed a framework for analysing changes in resilience to cope with periods of dry conditions. There have so far been few examples in the literature of empirical studies on changes in socio-ecological resilience in agricultural landscapes. The development of the framework occurred over four steps where we first analysed the identity of the system and its potential alternative domains of development, with a special focus on the relation to land degradation and drought. In the second step we identified two social-ecological variables (the ecosystem insurance capacity and the soil water index) that seem to determine the dynamics of the system and we discussed how they maintained feedback loops in the different 
domains. These variables, however, are difficult to measure empirically. In the third step, we therefore analysed drivers for change in these variables and suggested measurable indicators. Using these variables, we then looked at how resilience has changed in the Makanya catchment since the mid-1950s.

We have argued that changes have resulted in the system moving from a 'productive domain' to an 'unproductive domain'. This means that the feedbacks in the system today erode its capacity to supply food and ecosystem services to Makanya's inhabitants, and degrade the resource base over time. We have also identified several trends that could lead to change. As is evident from the case study, social-ecological resilience can be either problematic (if it maintains destructive resource use) or positive (if it maintains a productive resource base). We considered how the internal resources of the system may be insufficient to enhance the resilience of the productive state, and argued that if poverty is to be reduced and resilience increased, external resources will almost certainly be needed.

\section{Acknowledgements}

The work reported here was undertaken as part of the Smallholder System Innovations in Integrated Watershed Management (SSI) Program supported by the Netherlands Foundation for the Advancement of Tropical Research (WOTRO), the Swedish International Development Cooperation Agency (Sida), the Netherlands DirectorateGeneral of Development Cooperation (DGIS), the International Water Management Institute (IWMI), UNESCO-IHE Institute for Water Education, Sokoine University of Agriculture (SUA), Tanzania, University of Kwa-Zulu Natal (UKZN), South Africa and Stockholm University (SU), Sweden. The Soil-Water Management Research group (SWMRG) of SUA assisted with the implementation of field research. Dr Gordon's work was co-funded by Sida/SAREC and FORMAS and part of her work for the paper was conducted during her Post-Doc at IWMI. Thanks to Deborah Bossio for comments on the manuscript, to Elena Bennett and Garry Peterson for discussions on regime shifts in agriculture and to Robert Kautsky for help with graphics.

\section{References}

Antle, J.H., Stoorvodel, J.J. and Valdivia, R.O. (2006) Multiple equilibria, soil conservation investments, and the resilience of agricultural systems. Environment and Development Economics 11 (4), 477-492.

Barrett, C.B. and Swallow, B.M. (2006) Fractal poverty traps. World Development 34 (1), 1-15.

Barrett, C.B., Reardon, T. and Webb, P. (2001) Nonfarm income diversification and household livelihood strategies in rural Africa: concepts, dynamics, and policy implications. Food Policy 26 (4), 315-331.

Barron, J., Rockström, J., Gichuki, F. and Hatibu, N. (2003) Dry spell analysis and maize yields for two semiarid locations in east Africa. Agricultural and Forest Meteorology 117 (1-2), 23-37.

Bennett, E.M. and Balvanera, P. (2007) The future of production systems in a globalized world. Frontiers in Ecology and the Environment 5(4), 191-198.

Bernard, H.R. (1994) Research Methods in Anthropology: Qualitative and Quantitative Approaches. Sage Publications, Thousand Oaks, UK.

Biggs, R., Bohensky, E., Desanker, P.V., Fabricius, C., Lynam, T.T., Misselhorn, A.A., Mosvoto, C., Mutale, M., Reyers, B., Scholes, R.J., Shikongo, S. and van Jaarsveld, A.S. (2004) Nature Supporting People: the Southern African Millennium Ecosystem Assessment (SAfMA). Council for Scientific and Industrial Research, Pretoria, South Africa.

Carpenter, S., Walker, B., Anderies, J.M. and Abel, N. (2001) From metaphor to measurement: resilience of what to what? Ecosystems, 4 (8), 765-781.

Carpenter, S.R., Westley, F. and Turner, M.G. (2005) Surrogates for resilience of social-ecological systems. Ecosystems 8 (8), 941-944.

Colding, J., Elmqvist, T. and Olsson, P. (2003) Living with disturbance: building resilience in social-ecological systems. In Berkes, F., Colding, J. and Folke, C. (eds) Navigating Social-Ecological Systems: Building Resilience for Complexity and Change. Cambridge University Press, Cambridge, UK, pp. 163-185.

Cumming, G.S. and Spiesman, B. (2006) Regional problems need integrated solutions: pest management and conservation biology in agroecosystems. Biological Conservation 131, 533-543. 
Ellis, F. (1998) Household strategies and rural livelihood diversification. Journal of Development Studies 35 (1), 1-38.

Elmqvist, T., Colding, J., Barthel, S., Borgström, S., Duit, A., Lundberg, J., Ahrne, A.E.K., Ernstson, H., Folke, C. and Bengtsson, J. (2004) The dynamics of social-ecological systems in urban landscapes: Stockholm and the National Urban Park, Sweden. Annals of the New York Academy of Sciences 1023, 308-322.

Enfors, E. and Gordon, L.J. (2007) Analysing resilience in dryland agro-ecosystems: a case study of the Makanya catchment in Tanzania over the past 50 years. Land Degradation and Development 18 (6), 680-696.

Fernandez, R.J., Archer, E.R.M., Ash, A.J., Dowlatabadi, H., Hiernaux, P.H.Y., Reynolds, J.F., Vogel, C.H., Walker, B.H. and Wiegand, T. (2002) Degradation and recovery in socio-ecological systems: a view from the household/farm level. In: Reynolds, J.F. and Stafford Smith, D.M. (eds) Global Desertification: Do Humans Cause Deserts? Dahlem University Press, Berlin, pp. 297-323.

Foley, J.A., Defries, R., Asner, G.P., Barford, C., Bonan, G., Carpenter, S.R., Chapin, F.S., Coe, M.T., Daily, G.C., Gibbs, H.K., Helkowski, J.H., Holloway, T., Howard, E.A., Kucharik, C.J., Monfreda, C., Patz, J.A., Prentice, I.C., Ramankutty, N. and Snyder, P.K. (2005) Global consequences of land use. Science 309 (5734), 570-574.

Folke, C. (2006) Resilience: the emergence of a perspective for social-ecological systems analyses. Global Environmental Change 16, 253-267.

Folke, C., Carpenter, S., Walker, B., Scheffer, M., Elmqvist, T., Gunderson, L. and Holling, C.S. (2004) Regime shifts, resilience, and biodiversity in ecosystem management. Annual Review of Ecology Evolution and Systematics 35, 557-581.

Gordon, L., Steffen, W., Jonsson, B.F., Folke, C., Falkenmark, M. and Johannesssen, A. (2005) Human modification of global water vapor flows from the land surface. Proceedings of the National Academy of Sciences 102 (21), 7612-7617.

Gunderson, L.H. and Holling, C.S. (eds) (2002) Panarchy: Understanding Transformations in Human and Natural Systems. Island Press, Washington, DC.

IFPRI (International Food Policy Research Institute) (2005) The future of small farms. Proceedings of a research workshop, Wye, UK, 26-29 June 2005. IFPRI, Washington, DC.

Jordan, N., Boody, G., Broussard, W., Glover, J.D., Keeney, D., McCown, B.H., Mclsaac, G., Muller, M., Murray, H., Neal, J., Pansing, C., Turner, R.E., Warner, K. and Wyse, D. (2007) Environment: sustainable development of the agricultural bio-economy. Science 316 (5831), 1570-1571.

Kareiva, P., Watts, S., McDonald, R. and Boucher, T. (2007) Domesticated nature: shaping landscapes and ecosystems for human welfare. Science 316 (5833), 1866-1869.

Kingdon, J.W. (1995) Agendas, Alternatives, and Public Policies. Harper Collins, New York.

Klein, A.M., Vaissière, B., Cane, J.H., Steffan-Dewenter, I., Cunningham, S.A., Kremen, C. and Tscharntke, T. (2007) Importance of crop pollinators in changing landscapes for world crops. Proceedings of the Royal Society B: Biological Sciences 274, 303-313.

Koning, N. and Smaling, E. (2005) Environmental crisis or 'lie of the land'? The debate on soil degradation in Africa. Land Use Policy 22 (1), 3-11.

Kremen, C., Williams, N.M., Aizen, M.A., Gemmill-Herren, B., LeBuhn, G., Minckley, R., Packer, L., Potts, S.G., Roulston, T., Steffan-Dewenter, I., Vázquez, D.P., Winfree, R., Adams, L., Crone, E.E., Greenleaf, S.S., Keitt, T.H., Klein, A., Regetz, J. and Ricketts, T.H. (2007) Pollination and other ecosystem services produced by mobile organisms: a conceptual framework for the effects of land-use change. Ecology Letters 10 (4), 299-314.

MEA (Millennium Ecosystem Assessment) (2005) Ecosystems and human wellbeing: desertification synthesis. World Resources Institute, Washington, DC.

Mikkelsen, B. (1995) Methods for Development Work and Research: a Guide for Practitioners. Sage Publications, New Delhi.

Molden, D.J. (ed.) (2007) Water for Food, Water for Life: a Comprehensive Assessment of Water Management in Agriculture. Earthscan, London and the International Water Management Institute, Colombo, Sri Lanka.

Mortimore, M. (2005) Dryland development: success stories from West Africa. Environment 47 (1), 8-21.

Niamir-Fuller, M. (1998) The resilience of pastoral herding in Sahelian Africa. In: Berkes, F., Colding, J. and Folke, C. (eds) Navigating Social-Ecological Systems: Building Resilience for Complexity and Change. Cambridge University Press, Cambridge, UK, pp. 250-284.

North, D. (1990) Institutions, Institutional Change and Economic Performance. Cambridge University Press, Cambridge, UK. 
Olsson, P., Gunderson, L.H., Carpenter, S.R., Ryan, P., Lebel, L., Folke, C. and Holling, C.S. (2006) Shooting the rapids: navigating transitions to adaptive governance of social-ecological systems. Ecology and Society 11 (1), 18.

Reynolds, J.F., Smith, D.M.S., Lambin, E.F., Turner, B.L. II, Mortimore, M., Batterbury, S.P.J., Downing, T.E., Dowlatabadi, H., Fernández, R.J., Herrick, J.E., Huber-Sannwald, E., Jiang, H., Leemans, R., Lynam, T., Maestre, F.T., Ayarza, M. and Walker, B (2007) Global desertification: building a science for dryland development. Science 316 (5826), 847-851.

Rockström, J. (2000) Water resources management in smallholder farms in eastern and southern Africa: an overview. Physics and Chemistry of the Earth Part B - Hydrology Oceans and Atmosphere 25 (3), 275-283.

Rockström, J. (2003) Resilience building and water demand management for drought mitigation. Physics and Chemistry of the Earth 28 (20-27), 869-877.

SEI (Stockholm Environment Institute) (2005) Sustainable pathways to attain the millennium development goals: assessing the key role of water, energy and sanitation. SEI, Stockholm, Sweden.

Speranza, C.I, Kiteme, B. and Wiesmann, U. (2008) Droughts and famines: the underlying factors and the causal links among agro-pastoral households in semi-arid Makueni district, Kenya. Global Environmental Change 18 (1), 220-233.

Steffen, W., Sanderson, A., Tyson, P., Jäger, J., Matson, P., Moore, B. III, Oldfield, F., Richardson, K., Schellnhuber, H-J., Turner, B.L. II and Wasson, R. (2004) Global Change and the Earth System: a Planet Under Pressure. IGBP Global Change Series. Springer-Verlag, Berlin.

Tengö, M. and Hammer, M. (2003) Management practices for building adaptive capacity: a case from northern Tanzania. In: Berkes, F., Colding, J. and Folke, C. (eds) Navigating Social-Ecological Systems: Building Resilience for Complexity and Change. Cambridge University Press, Cambridge, UK, pp. 132-162.

Tiffen, M., Mortimore, M. and Gichuki, F. (1994) More People, Less Erosion: Environmental Recovery in Kenya. Wiley, London.

United Republic of Tanzania (2002) Population and housing census. Central Bureau of Statistics, Dar es Salaam, Tanzania.

World Bank (2005) World Development Indicators 2005. World Bank, Development Data Center, Washington, DC.

WRI (World Resources Institute) (2005) World Resources 2005: the Wealth of the Poor - Managing Ecosystems to Fight Poverty. WRI, Washington, DC. 